\title{
Penggunaan Multimedia Pembelajaran Interaktif terhadap Kemampuan Koneksi Matematis Siswa Kelas XI MIPA SMA
}

\author{
Beni Junedi ${ }^{1, *}$, Epi Prahma Sari ${ }^{2}$ \\ ${ }^{1}$ Universitas Bina Bangsa \\ ${ }^{2}$ STKIP Insan Madani Airmolek \\ *beni.junedi@binabangsa.ac.id
}

\begin{tabular}{|l|l|l|}
\hline Received : 8-4-2020 & Revised: $11-4-2020$ & Accepted: $11-4-2020$ \\
\hline
\end{tabular}

\begin{abstract}
ABSTRAK
Latar belakang masalah dalam penelitian ini adalah rendahnya kemampuan koneksi matematis siswa. Kesulitan siswa berupa mencari hubungan antar topik materi, materi dengan ilmu lain, dan materi dengan permasalahan kehidupan sehari-hari sehingga pembelajaran hanya terfokus pada konsep dari materi tersebut. Terbatasnya media pembelajaran yang membantu siswa memahami materi secara aktif. Penelitian ini bertujuan untuk mengetahui kemampuan koneksi matematis siswa dengan menggunakan multimedia pembelajaran interaktif. Jenis penelitian adalah penelitian quasy experimental design. Rancangan penelitian yang digunakan randomized subjects posttest only control group design. Teknik pengambilan sampel cluster random sampling. Setelah sampel diambil secara acak, terpilih siswa kelas XI MIPA 3 sebagai kelas eksperimen dan siswa kelas XI MIPA 1 sebagai kelas kontrol. Instrumen dalam penelitian berupa tes kemampuan koneksi matematis siswa. Teknik analisis data menggunakan uji Independent Samples T-Test (uji t ) dengan melakukan uji normalitas dan uji homogenitas sebagai uji prasyarat. Hasil uji hipotesis diperoleh nilai signifikansi $=0,001$ dan $\alpha=0,05$. Karena sig. $<\alpha$ atau $0,001<0,05$, maka terima $\mathrm{H}_{1}$ dan tolak $\mathrm{H}_{0}$. Disimpulkan bahwa kemampuan koneksi matematis siswa dengan pembelajaran menggunakan multimedia pembelajaran interaktif lebih baik daripada kemampuan koneksi matematis siswa dengan pembelajaran konvensional.
\end{abstract}

Kata Kunci: Multimedia Pembelajaran Interaktif, Kemampuan Koneksi Matematis

\section{ABSTRACT}

The background problem in this study is the low ability of students' mathematical connections. Difficulties of students in the form of looking for relationships between material topics, materials with other sciences, and materials with problems of daily life so that learning is only focused on the concept of the material.Limited learning media that helps students understand the material actively. This study aims to determine the ability of students' mathematical connections by using interactive learning multimedia. This type of research is a quasy experimental design research. The study design used was randomized subjects posttest only control group design. Cluster random sampling technique. After the sample is taken randomly, students of Class XI MIPA 3 are selected as the experimental class and students of Class XI MIPA 1 are selected as the control class. The instrument in the study was a student's mathematical connection ability test. The data analysis technique used independent Samples T-Test (t-test)by conducting a normality test and a homogeneity test as a prerequisite test. Hypothesis test results obtained significance value $=0.001$ and $\alpha=0.05$. Because sig. $<\alpha$ or $0.001<0.05$, then accept $H 1$ and reject HO. It was concluded that students 'mathematical connection skills with learning using interactive learning multimedia were better than students' mathematical connection abilities with conventional learning.

Keywords: Interactive Learning Multimedia, Mathematical Connection Ability 


\section{PENDAHULUAN}

Koneksi matematis merupakan kemampuan berpikir tingkat tinggi, yang mengaitkan antar konsep dalam matematika baik secara internal yaitu berhubungan dengan matematika itu sendiri maupun keterkaitan secara eksternal yaitu matematika dengan bidang lain dalam kehidupan sehari-hari (Ni'mah, Setiawani, \& Oktavianingtyas, 2017; Septian \& Komala, 2019). Kemampuan koneksi antar konsep akan memudahkan siswa untuk merumuskan secara induktif maupun deduktif konsep, ide, dan prosedur matematis yang baru untuk dapat diterapkan dalam menyelesaikan masalah matematika atau masalah dalam disiplin ilmu lainnya (Inayah, Septian, \& Suwarman, 2020; Ni'mah et al., 2017). Kemampuan koneksi matematis sangat dibutuhkan oleh siswa, karena dengan kemampuan ini siswa akan mampu menyelesaikan permasalahan-permasalahan dalam kehidupan yang saling berhubungan dengan erat. Namun, faktanya di sekolah kemampuan koneksi matematis siswa masih rendah, terutama pada siswa kelas XI MIPA di SMA Negeri 1 Rengat Barat. Berdasarkan hasil observasi awal ditemukan bahwa 58,3 \% siswa belum mampu memahami soal-soal yang berkaitan dengan koneksi matematis. Hasil observasi diperkuat oleh tes awal terhadap kemampuan koneksi matematis siswa. Tes awal kemampuan koneksi matematis siswa dilakukan pada tanggal 23 s/d 24 Juli 2019.Berikut ini merupakan nilai rata-rata tes awal kemampuan koneksi matematis siswa kelas XI MIPA di SMA Negeri 1 Rengat Barat.

Tabel 1.Nilai Rata-Rata Tes Awal Kemampuan Koneksi Matematis SiswaKelas XI MIPA di SMA Negeri 1 Rengat Barat.

\begin{tabular}{cccc}
\hline No & Kelas & $\mathrm{n}$ (banyak siswa) & Nilai rata-rata \\
\hline 1. & XI MIPA 1 & 35 & 57,15 \\
\hline 2. & XI MIPA 2 & 35 & 58,20 \\
\hline 3. & XI MIPA 3 & 35 & 59,57 \\
\hline
\end{tabular}

Berdasarkan Tabel 1,dapat dilihat bahwa siswa masih menunjukkan nilai dibawah KKM (Kriteria Ketuntasan Minimum) yang ditetapkan oleh SMA Negeri 1 Rengat Barat yaitu 68. Dari hasil tes awal kemampuan koneksi matematis siswa jelas bahwa masih banyak siswa yang belum mampu menyelesaikan permasalahan matematika yang menggunakan dua konsep matematika sekaligus, matematika yang berkaitan dengan permasalahan sehari-hari, dan sebagainya (Maskur et al., 2020; Septian, 2017). Observasi lanjutan dilaukan pada tanggal 22 Juli 2019 untuk melihat proses pembelajaran yang 
dilaksanakan oleh guru. Berdasarkan hasil observasi diperoleh data bahwa sebahagian siswa menganggap matematika sebagai mata pelajaran yang sangat sulit, tidak menyenangkan, bahkan menakutkan, sehingga siswa belum memiliki motivasi yang kuat dalam mengikuti pelajaran. Disamping itu guru metodologi pembelajaran yang diterapkan oleh guru masih bersifat monoton. Permasalahan yang terbesar adalah guru sudah menggunakan media di dalam pembelajaran akan tetapi masih menggunakan media yang sederhana, sehingga kurang menarik minat siswa untuk belajar (Hendriawan \& Septian, 2019; Septian, 2017).

Berdasarkan permasalahan tersebut perlu solusi yang tepat untuk meningkatkan kemampuan koneksi matematis siswa, salah satu solusi adalah menerapkan multimedia pembelajaran interaktif. Multimedia pembelajaran interaktif sangat efektif digunakan di dalam proses pembelajaran karena sangat membantu guru dan siswa (Karimah, Rusdi, \& Fachruddin, 2017). Penggunaan multimedia pembelajaran interaktif dalam proses pembelajaran di respon tinggi/sangat baik oleh siswa(Sanusi, Suprapto, \& Apriandi, 2015). Media Pembelajaran Interaktif dapat menbangkitkanmotivasi belajar siswa, dan interaksi secara langsung antara siswa dan lingkungannya (Zulhelmi, Adlim, 2017). Multimedia pembelajaran interaktif merupakan pembelajaran dengan menggunakan berbagai media yang dilengkapi dengan alat pengontrol yang dapat dioperasikan oleh pengguna dan pengguna dapat memilih apa pembelajarn yang dikehendaki (Karimah et al., 2017). Pengguna akan terlibat aktif dengan komputer dimana pengguna akan menjalankan komputer berdasarkan yang ia inginkan dan komputer akan menampilkan yang diinginkan pengguna. Interaksi antara pengguna (siswa) dan komputer pada multimedia inilah yang dinamakan dengan multimedia pembelajaran interaktif.

Dengan penggunaan multimedia pembelajaran interaktif pembelajaran akan menyenangkan karena penampilan multimedia dirancang semenarik mungkin, siswa akan fokus memahami materi pembelajaran karena materi tersebut sudah ada di dalam multimedia itu sendiri, siswa memiliki waktu yang cukup untuk memahami materi sehingga memiliki kesempatan dalam mengulang dan mempelajari sendiri materi pelajaran terlebih dahulu. Dengan penggunaan multimedia pembelajaran interaktif guru memiliki cukup waktu untuk menyampaikan materi yang sedang dibahas dan dapat menghubungkan materi tersebut dengan materi matematika lain ataupun pada topik diluar matematika.

Tujuan penelitian dilaksanakan adalah untuk melihat apakah kemampuan koneksi matematis siswa dengan penggunaan multimedia pembelajaran interaktif lebih baik 
daripada kemampuan koneksi matematis siswa dengan pembelajaran konvensional di kelas XI MIPA SMA Negeri 1 Rengat Barat.

\section{METODE PENELITIAN}

Berdasarkan tujuan penelitian, jenis penelitian ini adalah penelitian eksperimen (experimental research). Metode eksperimen adalah suatu metode penelitian yang berusaha mencari hubungan variabel tertentu terhadap variabel lain dalam kondisi yang terkontrol secara ketat (Suharsimi, 2013).

Desain yang digunakan adalah Quasy Experimental Design. Desain ini mempunyai kelompok kontrol, tetapi tidak dapat berfungsi sepenuhnya untuk mengontrol variabelvariabel luar yang mempengaruhi pelaksanaan eksperimen.Bentuk desain eksperimen ini merupakan pengembangan dari True Experimental Design, yang sulit dilaksanakan. Walaupun kelompok kontrol pada Quasi Experimental Design initidak dapat berfungsi sepenuhnya, namun ini cukup membantu dalam proses penelitian.

Adapun rancangan penelitian yang digunakan adalah Randomized Subject Posttes only control group design dibawah ini: .

Tabel 2. Randomized Subject Posttes Only Control Group Design

(Hamid Darmadi, 2014)

\begin{tabular}{cccc}
\hline & Group & Variabel Terikat & Postest \\
\hline $\mathrm{R}$ & Eksperimen & $\mathrm{X}$ & $Y_{2}$ \\
\hline $\mathrm{R}$ & Kontrol & - & $Y_{2}$ \\
\hline
\end{tabular}

Keterangan :

$\mathrm{R}=$ Random

$\mathrm{X}=$ Perlakuan yang diberikan pada kelas eksperimen berupa pembelajaran menggunakan multimedia interaktif

$\mathrm{Y}_{2}=$ Tes untuk mengetahui kemampuan koneksi matematis siswa

Populasi dalam penelitian ini berjumlah 105 siswa yang merupakan jumlah seluruh siswa kelas XI MIPA. Sedangkan sampel dalam penelitian ini adalah siswa kelas XI MIPA 3 sebagai kelas eksperimen dengan pembelajaran menggunakan multimedia pembelajaran interaktifdan siswa kelas XI MIPA 1 sebagai kelas kontrol dengan pembelajaran konvensional.Instrumen yang digunakan dalam penelitian ini berupa tes essay. Teknik analisis data yang digunakan adalah analisis statistika inferensial. Analisis ini dilakukan terhadap $\mathrm{n}$ data hasil postest sesudah penelitian. Karena data berasal dari sampel yang saling bebas maka uji statitik yang digunakan terhadap dua sampel yang saling bebas yaitu dengan menggunakan uji " $\mathrm{t}$ " (Independent Sample $t$ Test) dengan uji normalitas dan homogenitas sebagai uji prasyaratnya. 


\section{HASIL DAN PEMBAHASAN}

Hasil perhitungan uji normalitas keduasampel dapat dilihat pada tabel berikut.

Tabel 3. Hasil Analisis Uji Normalitas Kelas Sampel

\begin{tabular}{ccc}
\hline Kelas & Nilai Signifikan & Keterangan \\
\hline Eksperimen & 0,082 & Normal \\
\hline Kontrol & 0,200 & Normal \\
\hline
\end{tabular}

Berdasarkan Tabel 3, diperoleh bahwa nilai signifikan pada kelas eksperimen adalah 0,082 dan nilai signifikan pada kelas kontrol adalah 0,200. Karena signifikan pada kedua kelas sampel lebih besar dari 0,05 atau sig. $>\alpha$ maka dapat disimpulkan bahwa kedua kelas sampel berdistribusi normal.

Setelah melakukan uji normalitas pada kelas sampel maka analisis dilanjutkan dengann uji homogenitas pada kelas sampel. Uji homogenitas dilakukan agar dapat melihat apakah kedua sampel mempunyai variansi yang homogen atau tidak. Berdasarkan uji homogenitas tes akhir kedua sampel yang telah dilakukan diperoleh sig. $>\alpha$, yaitu $0,911>$ 0,05. Dikarenakan sig. $>\alpha$, maka dapat disimpulkan bahwa kedua kelas sampel memiliki variansi yang homogen.

Setelah dilakukan uji normalitas dan uji homogenitas pada sampel dan diperoleh bahwa sampel berdistribusi normal dan memiliki variansi yanghomogen maka analisis dapat dilanjutkan dengan uji hipotesis dengan cara menggunakan Uji-t. Berdasarkan hasil uji hipotesis diperoleh nilai sig. $<0,05$ yaitu $0,001<0,05$ dengan(df) n-2 maka keputusan yang diambil adalah terima $H_{l}$ dan tolak $H_{0}$. Dapat disimpulkan bahwa rata-rata kemampuan koneksi matematis siswa dengan penggunaan multimedia pembelajaran interaktif lebih baik daripada rata-rata kemampuan koneksi matematis siswa dengan pembelajaran konvensional pada kelas XI MIPA SMA Negeri 1 Rengat Barat”.

Berdasarkan hasil penelitian yang telah dilakukan diperoleh kesimpulan bahwa rata-rata kemampuan koneksi matematis siswa dengan penggunaan multimedia pembelajaran interaktif lebih baik daripada rata-rata kemampuan koneksi matematis siswa dengan pembelajaran konvensional. Hal ini dikarenakan pada penggunaan multimedia pembelajaran interaktif guru memiliki waktu yang cukup untuk menyampaikan materi pembelajaran saat itu dan memperdalam indikator kemampuan koneksi matematis siswa. Berikut ini disajikan deskripsi dari bentuk-bentuk indikator kemampuan koneksi matematis siswa pada kelas eksperimen dan kelas kontrol yang diperoleh dari hasil tes akhir.

a) Mencari hubungan antar berbagai representasi konsep dan prosedur, serta memahami hubungan antar topik matematika. 
Kemampuan ini ditinjau dari hasil tes akhir pada soal nomor 1 berikut.

Soal nomor 1 .

Himpunan A adalah sebuah himpunan yang anggota-anggotanya hanya yang berada di dalam daerah penyelesaian sistem pertidaksamaan $y-x \geq 5,4 x+$ $3 y \leq 12, x \geq 0, y \leq 0$. Tentukanlah anggota dari himpunan A tersebut!

Dari kelas eksperimen,terlihat bahwa siswa sudah mampu mencari hubungan antar berbagai representasi konsep dan prosedur, serta memahami hubungan antar topik matematika. Hal tersebut dapat dilihat dengan jawaban siswa yang terurut, mulai dari menyatakan konsep SPtLDV kemudian dilanjutkan dengan menentukan daerah penyelesaian menggunakan prosedur SPtLDV. Setelah memperoleh daerah penyelesaian SPtLDV tersebut, siswa melanjutkan dengan menghubungkan pada konsep himpunan dan menyatakan anggota himpunan A berdasarkan prosedur dari menyatakan anggota suatu himpunan.

Sedangkan jawaban siswa pada kelas kontrol, terlihat bahwa siswa belum mampu mencari hubungan antar berbagai representasi konsep dan prosedur, serta memahami hubungan antar topik matematika. Hal tersebut dapat dilihat dengan jawaban siswa hanya dapat menyelesaikan pada menentukan daerah penyelesaian menggunakan prosedur SPtLDV saja. Setelah menentukan daerah penyelesaian siswa tidak dapat menyatakan anggota himpunan A dengan jelas dan tepat sesuai dengan konsep dan prosedur himpunan. Namun tidak semua siswa pada kelas kontrol yang belum mampu mencari hubungan antar berbagai representasi konsep dan prosedur, serta memahami hubungan antar topik matematika

Berdasarkan deskripsi terhadap jawaban siswa pada kelas eksperimen dan kelas kontrol, terlihat bahwa kemampuan mencari hubungan antar berbagai representasi konsep dan prosedur, serta memahami hubungan antar topik matematika pada kelas eksperimen lebih baik daripada kelas kontrol. Pembelajaran Multimedia interaktif memiliki keuntungan yaitu mampu meningkatkan kemampuan siswa dalam matematika, kecepatan siswa dalam penguasaan konsep yang dipelajari lebih tinggi dan sikap siswa terhadap matematika menjadi lebih baik (Hakim \& Windayana, 2016). Hal ini dikarenakan pada kelas eksperimen pembelajarannya menggunakan multimedia pembelajaran interaktif dimana pada kegiatan pembelajaran disajikan dengan leluasa dan jelas tanpa terhambat oleh waktu yang terbatas sehingga dapat membantu siswa lebih mampu meningkatkan kemampuan mencari hubungan antar berbagai representasi konsep dan prosedur, serta memahami hubungan antar topik matematika. 
b) Memahami representasi ekuivalen konsep yang sama, mencari koneksi satu prosedur ke prosedur lain dalam representasi yang ekuivalen.

Soal nomor 2 .

Tentukan konstanta a yang memenuhi fungsi $f(x, y)=a x+4 y$ dengan kendala $x+y \geq 12, x+2 y \geq 16, x \geq 0, y \geq 0$ yang minimum pada $(8,4)$ !

Pada kelas eksperimen, terlihat bahwa siswa sudah mampu mahami representasi ekuivalen konsep yang sama, mencari koneksi satu prosedur ke prosedur lain dalam representasi yang ekuivalen. Penggunaan multimedia interaktif sebagai teknologi membantu siswa mempelajari fakta, memahami abstraksi dan mencapai tujuan-tujuan dalam tingkatan taksonomi kognitif yag lebih tinggi (Novitasari, 2016). Hal tersebut dapat dilihat dengan jawaban siswa yang terurut, mulai dari menyatakan konsep SPtLDV kemudian dilanjutkan dengan menentukan daerah penyelesaian, menentukan titik-titik pojok pada daerah penyelesaian, menentukan nilai-nilai dari fungsi. Setelah memperoleh nilai-nilai dari fungsi tujuan siswa melanjutkan menentukan nilai konstanta a menggunakan hubungan prosedur nilai-nilai dari fungsi tujuan ke prosedur aljabar linear.

Sedangkan jawaban siswa pada kelas kontrol, terlihat bahwa siswa belum mampu memahami representasi ekuivalen konsep yang sama, mencari koneksi satu prosedur ke prosedur lain dalam representasi yang ekuivalen. Hal tersebut dapat dilihat dengan jawaban siswa yang hanya mampu menyelesaikan pada menentukan daerah penyelesaian dan tidak mampu menenentukan nilai dari konstanta a. Namun ada beberapa siswa pada kelas kontrol yang mampu memahami representasi ekuivalen konsep yang sama, mencari koneksi satu prosedur ke prosedur lain dalam representasi yang ekuivalen.

c) Mencari hubungan berbagai representasi konsep dan prosedur.

Soal nomor 3 .

Tentukan diagonal-diagonal dari daerah penyelesaian sistem pertidaksamaan linear berikut!

$$
\left\{\begin{array}{c}
5 x-2 y \geq-20 \\
3 x+5 y \leq 19 \\
x+2 y \geq-4 \\
5 x-y \leq 13
\end{array}\right.
$$

Pada kelas eksperimen, terlihat bahwa siswa sudah mampu mencari hubungan berbagai representasi konsep dan prosedur. Ketika siswa mampu mengasimilasikan materi atau konsep yang diperoleh dengan pengetahuan yang telah dimiliki sebelumnya menunjukan pemahaman siswa terhadap masalah (Widjayanti, Masfingatin, \& Setyansah, 2018). Hal tersebut dapat dilihat dengan jawaban siswa yang terurut, mulai dari menyatakan konsep SPtLDV kemudian dilanjutkan dengan menentukan daerah 
penyelesaian. Selanjutnya siswa memperjelas gambar yang terbentuk, dan menunjukkan diagonal dari daerah penyelesaian, berdasarkan bangun datar yang terbentuk.

Sedangkan jawaban siswa pada kelas kontrol, terlihat bahwa siswa belum mampu mencari hubungan berbagai representasi konsep dan prosedur. Hal tersebut dapat dilihat dengan jawaban siswa yang tidak mampu menentukan diagonal-diagonal dari daerah penyelesaian tersebut dikarenakan siswa tidak mengingat yang masa suatu diagonal. Siswa tidak mampu menentukan diagonal yang diminta. Namun, ada beberapa siswa pada kelas kontrol yang mampu memahami representasi ekuivalen konsep yang sama, mencari hubungan berbagai representasi konsep dan prosedur.

d) Menggunakan matematika dalam bidang studi lain atau kehidupan sehari-hari.

Soal nomor 4.

Penjahit A akan membuat pakaian wanita dan pria. Untuk membuat pakaian wanita diperlukan bahan bergaris $2 m$ dan bahan polos 1 m. Untuk membuat pakaian pria diperlukan bahan bergaris $1 \mathrm{~m}$ dan bahan polos $2 \mathrm{~m}$.Penjahit hanya memiliki persediaan bahan bergaris dan polos sebanyak 36m dan 30m. Jika pakaian wanita dijual dengan harga Rp150.000,00 dan pakaian priadijual dengan harga Rp100.000,00 tentukan pendapatan maksimum yang didapat!

Pada kelas eksperimen, terlihat bahwa siswa sudah mampu menggunakan matematika dalam bidang studi lain atau kehidupan sehari-hari. Peningkatan kemampuan koneksi matematis siswa ditunjukan dengan kemampuan siswa memahami koneksi antar keterampilan matematis dan koneksi matematis dengan mata pelajaran lain(Nanang Supriadi, 2015). Hal tersebut dapat dilihat dengan jawaban siswa yang terurut, mencari hubungan masalah tersebut dengan matematika yaitu bentuk SPtLDV yang memenuhi. Setelah mengetahui SPtLDV yang memenuhi dilanjutkan dengan nilai fungsi tujuan dengan setiap titik pojok dari daerah penyelesaiannya. Berdasarkan nilai fungsi tujuan dari setiap titik pojok diambil nilai tertinggi. Nilai tertinggi dari fungsi tujuan tersebut disebut sebagai nilai maksimum sehingga nilai maksimum itulah yang merupakan pendapatan maksimum penjahit tersebut.

Sedangkan jawaban siswa pada kelas kontrol, terlihat bahwa siswa belum mampu menggunakan matematika dalam bidang studi lain atau kehidupan sehari-hari. Hal tersebut dapat dilihat dengan jawaban siswa yang tidak mampu memodelkan permasalahan ke dalam model matematika dengan tepat. Hal tersebut mempengaruhi jawaban seterusnya. Namun ada beberapa siswa pada kelas kontrol yang mampu menggunakan matematika dalam bidang studi lain atau kehidupan sehari-hari. 
e) Menggunakan dan menilai keterkaitan antar topik matematika dan keterkaitan matematika dengan topik diluar matematika.

Soal nomor 5.

Riko menggambar sebuah segitiga sebagai suatu wilayah dalam permainan kelerengnya.Ternyata segitiga tersebut menunjukkan himpunan penyelesaian dari suatu SPtLDV. Jika segitiga tersebut dilukis pada bidang cartesius, maka masing-masing sudutnya berada pada titik (4,1), (6,6), dan $(3,4)$. Tentukan SPtLDV dan nilai minimum dari fungsi tujuan $f(x, y)=2 x+3 y$ menggunakan metode garis selidik!

Pada kelas eksperimen, terlihat bahwa siswa sudah menggunakan dan menilai keterkaitan antar topik matematika dan keterkaitan matematika dengan topik diluar matematika. Koneksi matematis menekankan kepada kemampuan dalam mengaitkan atau menghubungkan ide-ide matematika dengan keadaan lain, baik itu secara internal yaitu dengan pembelajaran matematika itu sendiri maupun secara eksternal yaitu pembelajaran di luar matematika (Ulya, I. F., Irawati, R., 2016). Hal tersebut dapat dilihat dengan jawaban siswa yang terurut, mencari hubungan masalah tersebut dengan matematika yaitu dengan menentukan bentuk SPtLDV yang memenuhi dengan menggunakan rumus mencari persamaan garis lurus.Setelah mengetahui SPtLDV yang memenuhi dilanjutkan dengan melukis atau menggambar daerah penyelesaian pada bidang cartesius. Selanjutnya menentukan persamaan garis selidik. Setelah diperoleh persamaan garis selidik, maka dilanjutkan dengan menggambar garis-garis selidik yang sejajar. Kemudian menentukan nilai optimum fungsi objektif dan dilanjutkan dengan menentukan nilai minimum dari fungsi objektif tersebut.

Sedangkan jawaban siswa pada kelas kontrol, terlihat bahwa siswa belum mampu menggunakan dan menilai keterkaitan antar topik matematika dan keterkaitan matematika dengan topik diluar matematika. Hal tersebut dapat dilihat dengan jawaban siswa yang tidak dapat menyelesaikan permasalahan tersebut. Namun ada beberapa siswa pada kelas kontrol yang mampu menggunakan dan menilai keterkaitan antar topik matematika dan keterkaitan matematika dengan topik diluar matematika.

\section{KESIMPULAN}

Berdasarkan hasil pengujian hipotesis diperoleh rata-rata kemampuan koneksi matematis siswa dengan penggunaan multimedia pembelajaran interaktif lebih baik daripada rata-rata kemampuan koneksi matematis siswa dengan pembelajaran konvensional di kelas XI MIPA SMA Negeri 1 Rengat Barat. Dengan demikian, dapat disimpulkan bahwa terdapat pengaruh signifikan penggunaan multimedia pembelajaran 
interaktif terhadap kemampuan koneksi matematis siswa kelas XI MIPA SMA Negeri 1 Rengat Barat.

\section{REFERENSI}

Hakim, A. R., \& Windayana, H. (2016). Pengaruh Penggunaan Multimedia Interaktif Dalam Pembelajaran Matematika Untuk Meningkatkan Hasil Belajar Siswa SD. EduHumaniora | Jurnal Pendidikan Dasar Kampus Cibiru, 4(2). https://doi.org/10.17509/eh.v4i2.2827

Hamid Darmadi. (2014). Metode Penelitian Pendidikan dan Sosial. In Metode Penelitian Pendidikan dan Sosial.

Hendriawan, M. A., \& Septian, A. (2019). Pengembangan JiMath Sebagai Multimedia Pembelajaran Matematika Berbasis Android Untuk Siswa Sekolah Menengah Atas. IndoMath: Indonesia Mathematics 45. https://doi.org/10.30738/indomath.v2i1.2785

Inayah, S., Septian, A., \& Suwarman, R. F. (2020). Student Procedural Fluency in Numerical Method Subjects. Desimal: Jurnal Matematika, 3(1), 53-64. https://doi.org/10.24042/djm.v3i1.5316

Karimah, A., Rusdi, R., \& Fachruddin, M. (2017). Efektifitas media pembelajaran matematika menggunakan software animasi berbasis multimedia interaktif model tutorial pada materi garis dan sudut untuk siswa SMP/Mts kelas VII. Jurnal Penelitian Pembelajaran Matematika Sekolah (JP2MS), 1(1), 9-13. https://doi.org/10.33369/jp2ms.1.1.9-13

Maskur, R., Sumarno, Rahmawati, Y., Pradana, K., Syazali, M., Septian, A., \& Palupi, E. K. (2020). The effectiveness of problem based learning and aptitude treatment interaction in improving mathematical creative thinking skills on curriculum 2013. European Journal of Educational Research, 9(1), 375-383. https://doi.org/10.12973/eu-jer.9.1.375

Nanang Supriadi. (2015). Pembelajaran Geometri Berbasis Geogebra sebagai Upaya Meningkatkan Kemampuan Komunikasi Matematis Siswa Madrasah Tsanawiyah (MTs). Al-Jabar: Jurnal Pendidikan Matematika, 6(2), 1-14.

Ni'mah, A. F., Setiawani, S., \& Oktavianingtyas, E. (2017). Analisis Kemampuan Koneksi Matematika Siswa Kelas IX A MTs Negeri 1 Jember Subpokok Bahasan Kubus dan Balok. Jurnal Edukasi, 4(1), 30. https://doi.org/10.19184/jukasi.v4i1.5087

Novitasari, D. (2016). Pengaruh Penggunaan Multimedia Interaktif terhadap Kemampuan Pemahaman Konsep Matematis Siswa. FIBONACCI: Jurnal Pendidikan Matematika Dan Matematika, 2(2), 8. https://doi.org/10.24853/fbc.2.2.8-18

Sanusi, S., Suprapto, E., \& Apriandi, D. (2015). Pengembangan Multimedia Interaktif sebagai Media Pembelajaran pada Pokok Bahasan Dimensi Tiga di Sekolah Menengah Atas (SMA). JIPM (Jurnal Ilmiah Pendidikan Matematika), 3(2). https://doi.org/10.25273/jipm.v3i2.510

Septian, A. (2017). Penerapan Geogebra untuk Meningkatkan Kemampuan Pemecahan Masalah Matematis Mahasiswa Program Studi Pendidikan Matematika Universitas Suryakancana. PRISMA, 6(2). https://doi.org/10.35194/jp.v6i2.212

Septian, A., \& Komala, E. (2019). Kemampuan Koneksi Matematik dan Motivasi Belajar Siswa dengan Menggunakan Model Problem-Based Learning (PBL) Berbantuan Geogebra di SMP. PRISMA, 8(1), 1-13. https://doi.org/10.35194/jp.v8i1.438

Suharsimi, A. (2013). Prosedur Penelitian: Suatu Pendekatan Praktik (Edisi Revisi). In Jakarta: Rineka Cipta. https://doi.org/10.1017/CBO9781107415324.004 
Ulya, I. F., Irawati, R., \& M. (2016). Peningkatan Kemampuan Koneksi Matematis dan Motivasi Belajar Siswa Menggunakan Pendekatan Kontekstual, 1(1), 121-130. https://doi.org/10.23819/pi.v1i1.2940

Widjayanti, W. R., Masfingatin, T., \& Setyansah, R. K. (2018). Media Pembelajaran Interaktif Berbasis Animasi pada Materi Statistika untuk Siswa Kelas 7 SMP. Jurnal Pendidikan Matematika, 13(1), 101-112. https://doi.org/10.22342/jpm.13.1.6294.101112

Zulhelmi, Adlim, \& M. (2017). Pengaruh Media Pembelajaran Interaktif terhadap Peningkatkan Keterampilan Berpikir Kritis Siswa. Jurnal Pendidikan Sains Indonesia (Indonesian Journal of Science Education), 5(1), 72-80. 